\title{
学童における声の音響パラメータの検討
}

\author{
奥田 晶史 ${ }^{1)}$ 玉井 ふ2 ${ }^{2)}$ 城本 修 ${ }^{2)}$
}

要 約 : 本研究では小学校低学年の母音発声時の音響パラメータ $P P Q, A P Q, N H R$ を検討 した. 対象は小学校 $1 \sim 3$ 年生の 88 例の健常学童である. 手続きは対象児に母音 [a] を声の高さ, 大きさが一定となるように 5 秒間持続発声させ，対象児 1 例について 2 試行行った. 音響分析 は Kay Model 4500 の Multi-Dimensional Voice Program 5105 を用いた。 その結果, PPQ で は 2 年生よりも 3 年生の測定平均值が有意に高かった. APQでは 1 回目に比して 2 回目の值

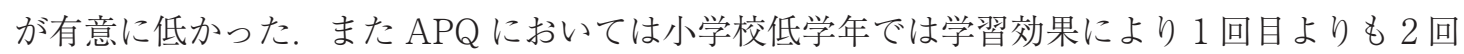
目の測定值が低下する可能性が示唆された。西尾ら（2002）の先行研究の若年成人のデータと 比較すると, 小学校低学年の測定平均值は若年成人の平均に比べて大きい值を取るパラメータ や，小さい值を取るパラメータがあり，若年成人と学童では正常範囲が異なる可能性が示唆さ れた。

索引用語 : 学童, 基本周期変動指数 ( $\mathrm{PPQ}$ ), 振幅変動指数 ( $\mathrm{APQ}$ ), 倍音に対する雑音の 割合 (NHR)，音響分析

\section{Acoustic Parameters during Phonation in Children}

\author{
Akifumi Okuda' ${ }^{1)}$ Fumi Tamai²) and Osamu Shiromoto
}

\begin{abstract}
The aim of this study was to investigate the values of three acoustic parameters (PPQ, APQ and NHR) in 88 normal elementary school children between the 1st and 3rd grades. The procedure called for the children to vocalize sustained phonation of the vowel [a] for 5 seconds, until a constant pitch of voice was achieved; each child underwent 2 trials. Acoustic analysis was carried out using the Multi-Dimensional Voice Program 5105 of Kay Model 4500. The results revealed that the mean PPQ was higher in the 3rd grade children than in the 2nd year children, with the mean APQ significantly lower in the 2nd trial than in the 1st. Comparing these data to those obtained by Nishio et al. (2002) it is clear that there may exist parameters yielding higher or lower values in children than in adults, suggesting that the normal range in adults may differ from that of school children. The results also suggested that APQ values may change in elementary school children depending on learning effect.
\end{abstract}

広島市西部こども療育センター1)：テ731-5138 広島市佐伯区海老山南 2-2-18

県立広島大学保健福祉学部コミュニケーション障害学科 ${ }^{2)}$ : †723-0053 広島県三原市学園町 1-1

${ }^{11}$ Hiroshima City Seibu Center for Children's Treatment and Guidance: 2-18, 2-chome, Kairoyamaminami, Saeki Ward, Hiroshima 731-5138, Japan

${ }^{2)}$ Department of Communication Sciences and Disorders, Prefectural University of Hiroshima: 1-1 Gakuencho, Mihara, Hiroshima 723-0053, Japan

2014 年 5 月 17 日受稿 2014 年 10 月 17 日受理 
Key words: elementary school children, $\mathrm{PPQ}, \mathrm{APQ}, \mathrm{NHR}$, voice analysis

\section{はじめに}

近年, 音響分析機器の進歩により，音響学的評価を 音声障害の臨床において日常的に活用することが多く なっている，基本周期変動指数（Pitch Perturbation Quotient: $\mathrm{PPQ}$ ), 振 幅変動 指 数 (Amplitude Perturbation Quotient: $\mathrm{APQ}$ )，倍音に対する雑音の 割合（Noise-to Harmonic Ratio: NHR）などの音響パ ラメータは，短時間に算出でき，音声障害の検出や治 療効果を定量的に評価することができる．臨床に音響 学的評価を応用する目的で開発された機器にはKay 社の Multi-Dimensional Voice Program（以下, MDVP) があり，簡便に音響パラメータの測定值を得ることが 可能である.MDVPの信頼性はすでに報告されてお $り^{1)}$ ， 日本語を母国語とし喉頭疾患および神経筋疾患 の既往がない若年成人 200 例（男性 100 例，平均年齢 21.5 歳, $\mathrm{SD}=1.82$ ，年齢範囲 19 29 歳，女性 100 例， 平均年齢 21.3 歳, $\mathrm{SD}=1.90$, 年齢範囲 19 31 歳）の 音響パラメータの正常範囲が明らかにされている2).

しかし，小児の音声に扮ける音響パラメータの研究 は，小児声带結節例と健常例を比較した研究があるも のの ${ }^{3)}$ ，例数が少ない，音響学的評価を臨床に応用す るにあたっては, 比較対象として多数の学童の音声サ ンプルから健常学童の音声の正常範囲を明らかにする ことが必要である。

また，声帯の長さ，声帯膜様部の長さは新生児より 年齢とともに増大し，20 歳頃に成人の長さに達する ことや ${ }^{4)}$ ，5１0 歳の間は声带の粘膜固有層浅層を欠 いていることが指摘されており，粘膜固有層浅層を欠 くことによって，声帯振動時に無理な負担が掛かりや すいと考えられている ${ }^{5,6)}$. したがって声帯の物理的 形状や層構造の違いにより，若年成人と学童の音声の 音響パラメータの測定值には差がある可能性がある. 仮に音響パラメータの測定值に若年成人と学童の間で 差があるならば，比較対象としての正常範囲は若年成 人者と学童で別途明らかにする必要がある。

そこで本研究では, 健常な小学校低学年学童 (小学 校 $1 \sim 3$ 年生） 88 例を対象とし, PPQ, APQ, NHR の音響パラメータについて西尾ら ${ }^{2)}$ が明らかにした若 年成人の正常範囲の平均, 標準偏差と比較, 検討を行っ た。

\section{方法}

\section{1．対象児}

保護者に同意を得た日本語を母語とする健聴の小学 校低学年学童（小学校 1 3 年生） 94 例（男児 52 例, 女児 42 例）に協力を依頼した。 また，全例，聴覚印 象上は嗄声を認めず，音声に異常がないことを言語聴 覚士が確認した。

年齢範囲は 6 歳 5 カ月 9 歳 5 カ月で, 平均年齢は 7 歳 10 カ月であった。男女間で月齢について検定し たところ，有意差は認めなかった。

\section{2. 手続き}

各学童に対して母音 $[\mathrm{a}]$ を声の高さ，大きさが一定 となるように教示した後，5秒間発声させ，DAT （SONY TCD-D10）に単一指向性マイク（SONY ECM-23F3）を接続して録音を行った。マイクと口唇 の距離は $15 \mathrm{~cm}$ で一定にした。サンプリング周波数 は $48 \mathrm{kHz}, 16$ ビット量子化で録音した。発声は 2 回 行い，続けて録音した。録音環境は静かな学校の教室 内で録音を行った。

分析は Computer Speech Lab (Kay Model 4500) の MDVP (Multi-Dimensional Voice Program 5105) を用いて行った。音声信号はDAT（SONY DTC2000ES）から Computer Speech Labに入力した.

分析区間は 5 秒間の発声の内, 中央の 3 秒間とし, 発声の起始と停止の過渡区間は除外した。分析区間を 3 秒間としたのは，MDVP 上で各パラメータを解析 するのにあたって，信頼できる測定値を得るのに十分 な持続時間であると考えられることによる1).

また, MDVP 上で, 基本周期, 振幅が分析できなかっ た学童 6 例の音声は除外し，88 例（男児 47 例，女児 41 例）の発声試行 2 回分の測定值を得た（表 1$) .88$ 例の年齢範囲は 6 歳 5 カ月 9 歳 5 カ月で, 平均年齢 は 7 歳 9 カ月であった。男女間で月齢について検定し たところ，有意差は認めなかった。

測定に関して，再度，男女 10 例ずつランダムサン プリングを行ったうえで同様の手続きにて音響分析を

表 1 対象学童の内訳

\begin{tabular}{lcccc}
\hline & 1 年生 & 2 年生 & 3 年生 & 計 \\
\hline 男児 & 21 & 17 & 9 & 47 \\
女児 & 11 & 13 & 17 & 41 \\
計 & 32 & 30 & 26 & 88 \\
\hline
\end{tabular}




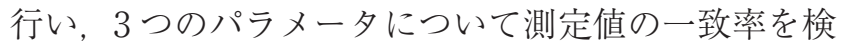
討した。 その結果，3つのパラメータとも測定值の一 致率は $100 \%$ で, 再検査信頼性は高いことが確認され た。

\section{3. 結果の処理}

各音響パラメータの測定值を従属変数とし, 学年 (1 年生, 2 年生, 3 年生の 3 水準), 性別（男児，女児の 2 水準), 発声試行 (1 回目の発声と 2 回目の発声の 2 水準) の繰り返しのある 3 元配置の分散分析を行い, 多重比較にはBonferroni/Dunnの方法を行った。統 計解析には, StatView（ver. 5, SAS）を使用した。 さらに，男女別に西尾ら ${ }^{2)}$ が明らかにした若年成人の 音声の音響パラメータの平均值と標準偏差を使用し て, 本研究で対象とした小学校 $1 \sim 3$ 年生学童 (以下, 小学校低学年全体) の 1 試行目と若年成人の各音響パ ラメー夕の值を $\mathrm{t}$ 検定で比較した。本来であれば小学 校 $1 \sim 3$ 年生学童と若年成人の個々の被験者の測定值 を基に分散分析を行うべきところ, 若年成人群につい ては文献から平均と標準偏差のみしかデー夕を得るこ とができなかったため, $\mathrm{t}$ 検定によって小学校 $1 \sim 3$ 年生学童と若年成人群の比較検定を行った.

\section{結果}

分散分析の結果, PPQ については学年の主効果が 認められた $(\mathrm{F}(2,82)=3.269, \mathrm{p}<.05)$. 多重比較の結 果, 2 年生に比して 3 年生の平均 $\mathrm{PPQ}$ 值が有意に高 かった（Bonferroni/Dunnの方法，p<.05). NHRに ついては学年, 性別, 発声試行の主効果および交互作 用はいずれも認めなかった. APQ については 1 回目 に比べ 2 回目の值が有意に低かった $(\mathrm{F}(1,82)=4.060$, $\mathrm{p}<.05)$ ．学年, 性別の主効果および交互作用はいずれ も認めなかった。

以下，各パラメータごとに西尾ら ${ }^{2)}$ が明らかにした 若年成人の平均值と今回得られた小学校低学年学童の 第 1 試行の平均值を比較した結果を示す.

$\mathrm{PPQ}$ については, 男女別に小学校 $1 \sim 3$ 年生学童 (以 下, 小学校低学年全体) の 1 試行目々若年成人の $\mathrm{PPQ}$ の平均值について $\mathrm{t}$ 検定を行い比較検討した結 果, 男女ともに若年成人に比して小学校低学年全体が 有意に高かった（男: $\mathrm{t}(145)=6.626, \mathrm{p}<.05$, 女: $\mathrm{t}$ （139） $=4.751, \mathrm{p}<.05)$. 各学年の 1 試行目の平均值と若年 成人の平均值を性別に比較すると, 若年成人男性より も小学校 1 年生, 2 年生, 3 年生男子の $\mathrm{PPQ}$ の平均值 はいずれも有意に高かった（1 年生男子： $\mathrm{t}(119)=$ $6.005, \mathrm{p}<.05,2$ 年生男子 $\mathrm{t}(115)=3.897, \mathrm{p}<.05,3$ 年
生男子 $: \mathrm{t}(107)=4.326, \mathrm{p}<.05)$ ，女性では若年成人女 性よりも小学校 1 年生女子, 3 年生女子の平均值は有 意に高く（ 1 年生女子 $\mathrm{t}(109)=2.416, \mathrm{p}<.05,3$ 年生 女子 $\mathrm{t}(115)=4.130, \mathrm{p}<.05)$ ，若年成人女性と小学校 2 年生の間では平均值に有意差は認めなかった（図 1 ).

$\mathrm{APQ}$ については, 小学校低学年男児全体の 1 試行 目の平均值と若年成人男性の平均值との間に有意差は 認めなかった，小学校低学年女児全体では若年成人女 性に比して小学校低学年女児全体の平均值が有意に高 かった（t $(139)=4.751, \mathrm{p}<.05)$ ．学年別の平均值と若 年成人の平均値を性別に比較すると，男性では若年成 人男性よりも小学校 1 年生男子が有意に高く（1 年生 男子 : $\mathrm{t}(119)=2.053, \mathrm{p}<.05)$, 若年成人男性と小学校 2 年生男子, 3 年生男子の間では有意差を認めなかっ た. 女性では若年成人女性よりも小学校 1 年生, 2 年生, 3 年生の $\mathrm{APQ}$ の平均值はいずれも有意に高かった（1 年生女子 : $\mathrm{t}(109)=3.187, \mathrm{p}<.05,2$ 年生女子 $\mathrm{t}(111)$ $=2.227, \mathrm{p}<.05,3$ 年生女子 $\mathrm{t}(115)=4.751, \mathrm{p}<.05 ） （$ 図 2).

NHR では小学校低学年全体の 1 試行目の平均值と 若年成人の NHR の平均值について $\mathrm{t}$ 検定を行い比較 検討した結果，小学校低学年男児全体は若年成人男性 よりも有意に低く（t $(145)=-8.807, \mathrm{p}<.05)$, 小学校 低学年女児全体と若年成人女性の間では有意差は認め なかった，各学年の 1 試行目の平均值と若年成人の平 均值を性別に比較すると, 男性では若年成人男性より も小学校 2 年生男子, 3 年生男子が有意に低く（2 年 生男子 $\mathrm{t}(115)=3.897,3$ 年生男子 $: \mathrm{t}(107)=4.326$, $\mathrm{p}<.05)$, 若年成人男性と 1 年生の間では有意差を認め なかった，若年成人女性と小学校各学年の間ではいず

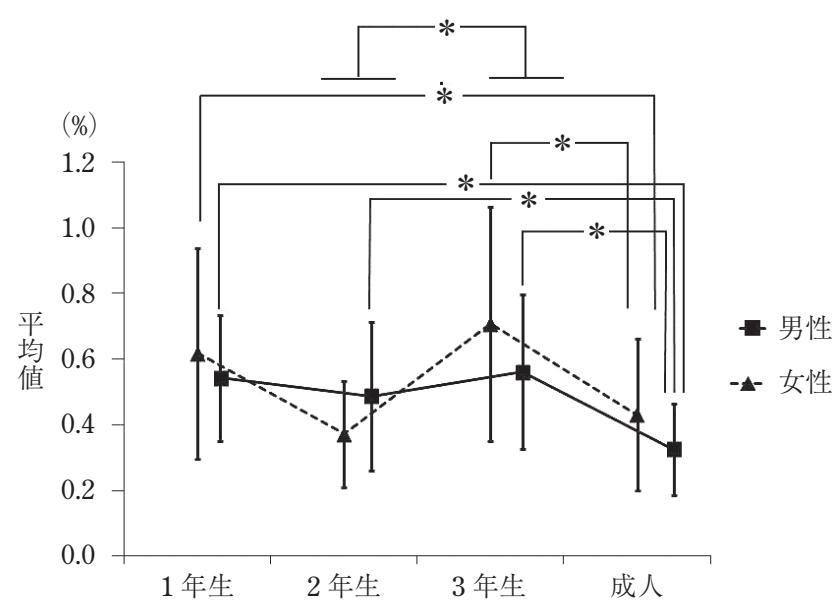

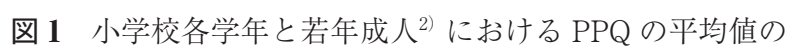
比較. エラーバーは 1 標準偏差を示す. ${ }^{*} \mathrm{p}<.05$ 
れも有意差を認めなかった（図 3 ）.

また, 各音響パラメータの平均 $95 \%$ 信頼区間を学 年別に算出した（表 2).

\section{考察}

\section{1. 発達による変化}

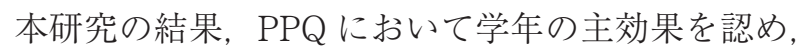
2 年生に比して 3 年生の $\mathrm{PPQ}$ の值が有意に高かった. しかし，APQ，NHRでは学年の主効果を認めなかっ た. $\mathrm{PPQ}$ でのみ 2 年生と 3 年生の間で有意差が認め られ，他のパラメータでは有意差を認めなかった点に ついてはさらに標本数を増やし，詳細に検討すること が必要と思われる。

小学校低学年学童の男女と西尾 ${ }^{2)}$ の若年成人男女 の比較では, $\mathrm{PPQ}$ の平均值が男女とも小学校低学年 学童が若年成人よりも有意に高かった。さらに女性で は $\mathrm{APQ}$ の平均值において小学校低学年学童が若年成 人よりも有意に高く，男性では NHR の平均值におい て小学校低学年学童が若年成人よりも有意に低かっ た。このことから, 学童から成人へと発達していく過 程で音響パラメータの平均值は変動が生じる可能性が あると考えられた。ささらに，女性の $\mathrm{APQ}$ ，男性の NHR の各音響パラメー夕については小学校低学年の 間は学年間で有意差はなかったことから，小学校低学
年以降の身体発達により，差が生じると推測される。

\section{2. 性差について}

本研究の結果からは，いずれのパラメータにおいて も小学校低学年（1３年生）の男女間に有意な差は なかった，西尾ら ${ }^{2)}$ の若年成人男女においては，PPQ では $\mathrm{p}<.01$ で男性に比して女性の平均值が高く, APQ では有意差なし，NHR においては $\mathrm{p}<.0001$ で女 性に比して男性の平均值が有意に高いという結果で あった，以上のことから，小学校低学年の期間では音 響パラメータに男女差はなく，若年成人に認められた 音響パラメータの性差は小学校低学年を過ぎてから生 じると推察される。声带長は 9 歳以下では男女間に差 はなく，15歳以上では男のほうが長いという報告が あり ${ }^{4)}$, 小学校高学年以降の声带長の変化によりこう した性差が生じている可能性を今後検討していくこと が必要と思われる。

\section{3. 測定の信頼性}

西尾ら ${ }^{2)}$ は健常青年を対象とする限りにおいては 1 回の測定で信頼できる值が測定できるが，安定した值 を得るためには 2 回の測定值の平均を求めるのが妥当 と報告している．今回の研究に抢ける3つの音響パラ メータは, APQについては学童では成人とは異なり, 2 回目の值が 1 回目の值よりも有意に低かった。この 原因としては発声を繰り返すことで, 学習効果が生じ

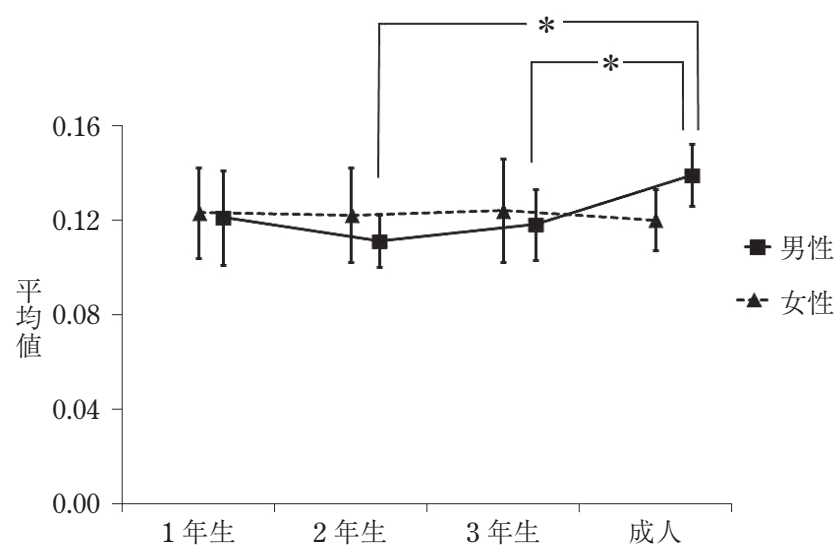

図 3 小学校各学年と若年成人 ${ }^{2)} に お け る ~ N H R$ の平均值の 比較.エラーバーは 1 標準偏差を示す. ${ }^{*} \mathrm{p}<.05$

表 2 各音響パラメータの平均の 95\%信頼区間

\begin{tabular}{|c|c|c|c|c|c|c|}
\hline & \multicolumn{2}{|c|}{1 年生 } & \multicolumn{2}{|c|}{2 年生 } & \multicolumn{2}{|c|}{3 年生 } \\
\hline & 男児 & 女児 & 男児 & 女児 & 男児 & 女児 \\
\hline PPQ（\%) & $0.444-0.612$ & $0.427-0.807$ & $0.357-0.585$ & $0.282-0.460$ & $0.361-0.733$ & $0.537-0.877$ \\
\hline $\mathrm{APQ}(\%)$ & $2.196-2.924$ & $2.401-3.125$ & $1.908-2.668$ & $1.951-3.187$ & $2.077-2.725$ & $2.402-3.490$ \\
\hline NHR & $0.035-0.207$ & $0.112-0.134$ & $0.106-0.116$ & $0.111-0.133$ & $0.108-0.128$ & $0.019-0.229$ \\
\hline
\end{tabular}


1 回目よりも 2 回目の值の振幅のゆらぎが減少した可 能性が考えられる．よって学童の臨床で音響分析を活 用する際は，そのことを考慮して複数回の測定を行う か， APQ 測定值の取り扱いに留意することが必要と 思われる.

\section{4. 今後の課題}

今後の課題としては，本研究では対象としなかった 小学校高学年, 中学生, 高校生などさらに対象を広げ, 幅広い年齢の音声を収集・分析することによって音響 パラメータの発達的変化について検討すること, 学童 と成人の声帯の物理特性の違いや声帯長の差異, さら に発声の安定性の差異が音響パラメータの測定值にど のような影響を及ぼすのかについて検討することが必 要であると思われる。

\section{まと め}

小学校低学年（1３年生）学童を対象に $\mathrm{PPQ}$, $\mathrm{APQ}, \mathrm{NHR}$ の 3 つ音響パラメー夕の值を収集し, 西尾ら ${ }^{2)}$ の若年成人のデー夕と比較検討を行った。

発達による変化については, 小学校低学年の平均は 若年成人の平均に比べて大きい值をとる音響パラメー 夕や，逆に小さい值をとるパラメータがあり，音響パ ラメータは若年成人と学童では正常範囲が異なる可能 性が示唆された，性差については，いずれのパラメー 夕においても認めなかった。発声試行については $\mathrm{APQ} に$ におては小学校低学年では学習効果により1
回目よりも 2 回目の測定值が低下する可能性があるた め，そのことを考慮して測定值を扱う必要があると考 えられた。

利益相反自己申告：申告すべきものなし．

\section{文献}

1) Kent RD, Vorperian HK and Duffy JR: Reliability of the Multi-Dimensional Voice Program for the analysis of voice samples of subjects with dysarthria. Am J Speech Lang Pathol, 8: 129-136, 1999.

2) 西尾正輝，新美成二：Multi-Dimensional Voice Program を用いた音声の解析，総合リハビリテーション，30（10）: 927-933, 2002.

3) Campisi P, Tewfik TL, Pelland-Blais E, et al: MultiDimensional Voice Program analysis in children with vocal cord nodules. J Otolaryngol, 29: 302-308, 2000.

4）栗田茂二郎 : 声帯の成長, 発達と老化一とくに層構造の加 齢的変化一. 音声言語医学, 29：185-193，1988.

5）山下耕太郎：ヒ下声帯粘膜固有層絨維構造の年齢的発達一 消化法を用いた走查型電子顕微鏡による観察一. 日耳鼻, $100:$ 499-511, 1997.

6）山下耕太郎, 石井甲介, 廣瀬 肇, 他：ヒ卜声带粘膜固有 層の年齢的発達一 5 歳以降の変化について一, 喉頭, 9 : 1-6, 1997.

別刷請求先： $\overline{7} 731-5138$ 広島市佐伯区海老山南 2-2-18 広島市西部こども療育センター 奥田晶史 